\section{Ano Internacional da Química será comemorado no mundo todo sob coordenação da Unesco}

O ano de 2011 é oficialmente o Ano Internacional da Química (AIQ). A data, coordenada pela Organização Cultural, Científica e Educacional das Nações Unidas (Unesco), tem um extenso programa em todo o mundo para celebrar as grandes descobertas e os avanços científicos e tecnológicos dessa que é uma das áreas mais ativas da ciência. A proposta é aumentar o interesse do público sobre a química, encorajando $o$ interesse entre os mais jovens para a área e gerando algum tipo de entusiasmo nesses indivíduos para que eles se tornem futuros químicos. A escolha da data também coincide com o centenário do Prêmio Nobel em Química entregue à física e química polonesa Marie Curie e, de acordo com a organização internacional do evento, isso seria uma forma de homenagear as descobertas e realizações das mulheres na ciência. O slogan da campanha internacional "Chemistry: our life, our future" (química: nossa vida, nosso futuro) foi adaptado, no Brasil, para "Química para um mundo melhor". "A proposta do AIQ é ter um olhar especial para a educação para a química, nos diversos níveis de formação, enfatizando as questōes ambientais e a sustentabilidade", aponta Cláudia Rezende, pesqui-

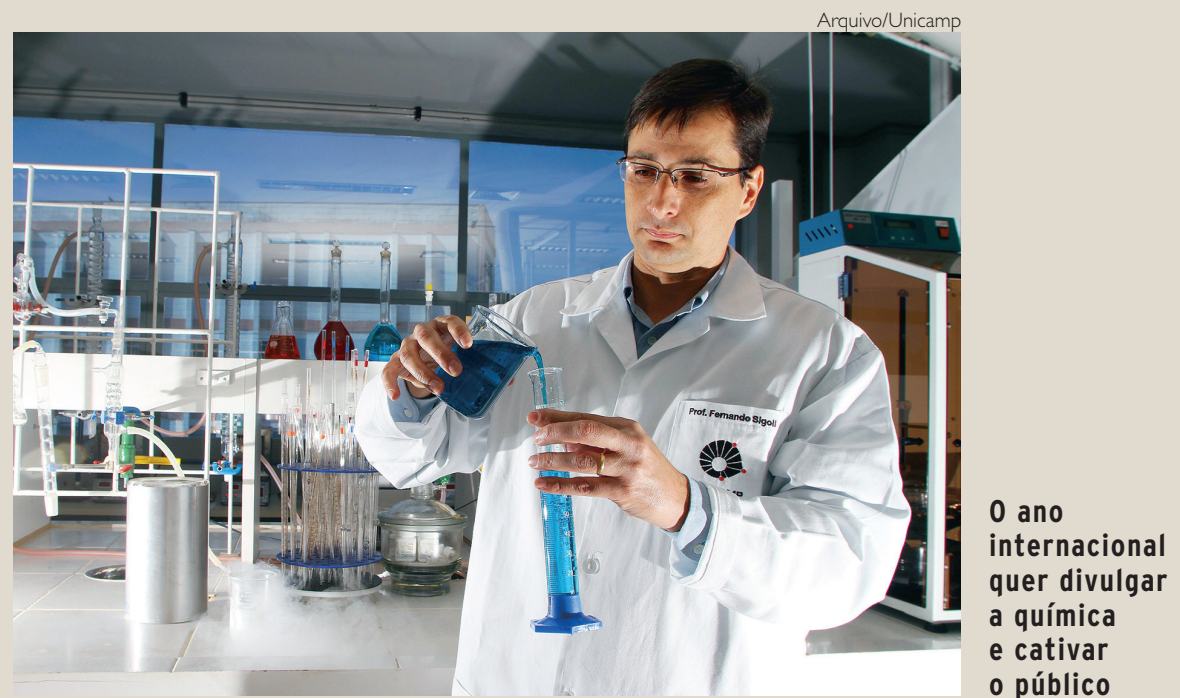

sadora do Instituto de Química, da Universidade Federal do Rio de Janeiro (UFRJ), e coordenadora nacional do Ano Internacional no país. Entre as propostas para essa comemoração no Brasil estão a criação de materiais paradidáticos virtuais - disponíveis através do Portal do Professor no site do Ministério da Educação (MEC) - e o lançamento de um DVD com experimentos de química para ser usado em sala de aula.

"O primeiro deles é uma coleção de ebooks sobre a química no cotidiano - química do amor, dos cosméticos, energia, saúde, alimentos, na natureza e nos esportes, por exemplo. Já o DVD de experimentos, intitulado "A química perto de você: experimentos para a sala de aula do ensino fundamental e médio", focará a parte prática”, explica Cláudia.

Outras açōes que estão em fase de desenvolvimento são exposições, mostras e atividades artísticas sobre essa área do conhecimento em todo o país. Além disso, também estão agendados diversos eventos que valorizem a formação de professores e licenciandos de química. "A ideia é provocar o questionamento do papel da química e sua adequação às premências da sustentabilidade", diz a pesquisadora.

\section{R\$2 MILHÕES PARA DIVULGAR E POPULA-} RIZAR A QUÍMICA NO BRASIL A primeira ação brasileira, promovidas pela Sociedade Brasileira de Química (SBQ) - que contou com o apoio do governo federal - foi criar um selo brasileiro através de uma campanha aberta à sociedade e um portal (www.quimica2011.org.br), que foi ao ar ainda em 2010.

Além disso, a SBQ também captou, em edital nacional junto ao Conselho Nacional de Desenvolvimento Científico e Tecnológico (CNPq), aproximadamente $\mathrm{R} \$ 2$ milhões, aberto aos projetos de divulgação e popularização da química. Os resultados do edital 48/2010 já estão disponíveis na página do orgão de fomento e incluem 47 projetos de quase todos os estados do Brasil. A programação final do AIQ 2011 está disponível aos interessados a partir do final do mês de janeiro.

Enio Rodrigo Barbosa 